\title{
CAR-T cell therapy in ovarian cancer: from the bench to the bedside
}

\author{
Xinxin Zhu ${ }^{1,2}$, Han Cai ${ }^{1}$, Ling Zhao ${ }^{1}$, Li Ning ${ }^{1}$ and Jinghe Lang ${ }^{1}$ \\ ${ }^{1}$ Department of Obstetrics and Gynecology, Peking Union Medical College Hospital, Peking Union Medical College, Chinese \\ Academy of Medical Sciences, Beijing, China \\ ${ }^{2}$ Department of Obstetrics and Gynecology, Institute for Wound Research, University of Florida, Gainesville, Florida, USA \\ Correspondence to: Jinghe Lang, email: langjh@hotmail.com, doctorlangjh@163.com \\ Keywords: chimeric antigen receptor, $T$ lymphocyte, immunotherapy, ovarian neoplasms, toxicity
}

Received: April 26, $2017 \quad$ Accepted: July 25, $2017 \quad$ Published: August 04, 2017

Copyright: Zhu et al. This is an open-access article distributed under the terms of the Creative Commons Attribution License 3.0 (CC BY 3.0 ), which permits unrestricted use, distribution, and reproduction in any medium, provided the original author and source are credited.

\section{ABSTRACT}

Ovarian cancer (OC) is the most lethal gynecological malignancy and is responsible for most gynecological cancer deaths. Apart from conventional surgery, chemotherapy, and radiotherapy, chimeric antigen receptor-modified T (CAR-T) cells as a representative of adoptive cellular immunotherapy have received considerable attention in the research field of cancer treatment. CARs combine antigen specificity and $\mathrm{T}$-cell-activating properties in a single fusion molecule. Several preclinical experiments and clinical trials have confirmed that adoptive cell immunotherapy using typical CAR-engineered $T$ cells for $O C$ is a promising treatment approach with striking clinical efficacy; moreover, the emerging CAR-Ts targeting various antigens also exert great potential. However, such therapies have side effects and toxicities, such as cytokine-associated and "on-target, off-tumor" toxicities. In this review, we systematically detail and highlight the present knowledge of CAR-Ts including the constructions, vectors, clinical applications, development challenges, and solutions of CAR-T-cell therapy for OC. We hope to provide new insight into OC treatment for the future.

\section{INTRODUCTION}

Ovarian cancer (OC) is the second most common gynecological malignancy in the United States, with 21,290 new cases in 2015 , and the most frequent cause of gynecological cancer-related mortality, with 14,180 estimated deaths in the same year [1]. Because of the insidious nature, limited screening tools, and nonspecific symptoms of OC, most patients are not diagnosed with OC until it has reached an advanced International Federation of Gynecology and Obstetrics stage [2]. The standard treatment for OC involves cytoreductive surgery, when necessary, followed by a combination of platinum- and taxane-based chemotherapy [3]. Although an initial response to chemotherapy occurs in more than $80 \%$ of patients, the cancer recurs in most patients, with an 18-month median time to progression $[4,5]$. Thus, novel and effective therapeutic approaches are urgently required to achieve a long-term favorable clinical prognosis for patients with OC. Adoptive T-cell immunotherapy is one of the most robust immunotherapy methods for treating cancers [6], and the early T-cell transfer trials enrolling patients with OC have yielded promising results $[7,8]$. Chimeric antigen receptor-modified $\mathrm{T}$ (CAR-T)-cell therapy is a representative variant of adoptive T-cell immunotherapy and has received considerable attention in the research and treatment of cancers. CAR-T-cell immunotherapy involves using gene transfer technology to reprogram patients' $T$ cells to express CARs, thereby directing the cytotoxic potential of $\mathrm{T}$ lymphocytes against cancer cells [9]. Numerous notable studies have revealed that CAR-T-cell immunotherapy is an effective therapeutic strategy for cancers including OC $[7,8,10,11]$. However, this therapy has side effects and related toxicities. In this systematic review, we present an overview of the biological understanding, clinical applications, and challenges of CAR-T-cell therapy in OC. 


\section{STRUCTURE OF CARs}

A chimeric antigen receptor (CAR) is a type of genetically engineered receptor. The structure of CARs comprises four parts: an extracellular antigen recognition region with single-chain variable fragments ( $\mathrm{scFvs}$ ), which derive from an antigen-specific $\mathrm{mAb}$ and recognize and bind specific tumor-related antigens independent of major histocompatibility complex (MHC) molecule restriction; an extracellular stalk (hinge) domain that typically comprises either $\mathrm{Fc}$ domains or the spacer domain from a cluster of differentiation 4 (CD4) and CD8 $[12,13]$; a transmembrane domain that is usually derived from $\mathrm{CD} 8, \mathrm{CD} 3-\zeta, \mathrm{CD} 4, \mathrm{OX} 40$, and $\mathrm{H} 2-\mathrm{K}^{\mathrm{b}}$ [14]; and an intracellular signaling tail including a signal-transduction component of a T-cell receptor (TCR) (e.g., CD3 $\zeta$ immunoreceptor tyrosine-based activation motif domain) and/or a costimulatory receptor (e.g., CD28, CD27, 4-1BB, or OX40) (Figure 1) [15]. The scFvs, formed by a combination of antibody heavy- and light-chain amino acid sequences with a short peptide linker, are attached to the hinge region, where they act as extracellular antigenbinding domains [16]. The variable region binds antigens and is capable of enormous combinatorial diversity, enabling the recognition of a myriad of specific molecular conformations [17]. The useful feature of an $\mathrm{scFv}$ comes from its "single chain" nature, which enables its incorporation into a CAR vector construct and efficient transduction into $\mathrm{T}$ cells. An scFv is characterized by its immunogenicity, affinity, specificity, and binding epitope [18]. With scFvs, CARs can specifically engage targets and trigger downstream signals.

CAR structures have evolved and there are now four generations used in clinical practice, the main distinctions between which are the presence of diverse costimulatory molecules (Figure 1). The primal CAR-T cell comprises a $\mathrm{scFv}$ fraction and signal-transduction domain $(\mathrm{CD} 3 \zeta$ or FceRI $\gamma$ ), which endows the modified $T$ cell with activation and homing abilities. Although preclinical experiments and early phase clinical trials using first-generation CAR-T

\section{CAR \\ CAR 2* \\ CAR 3* \\ CAR 4*}

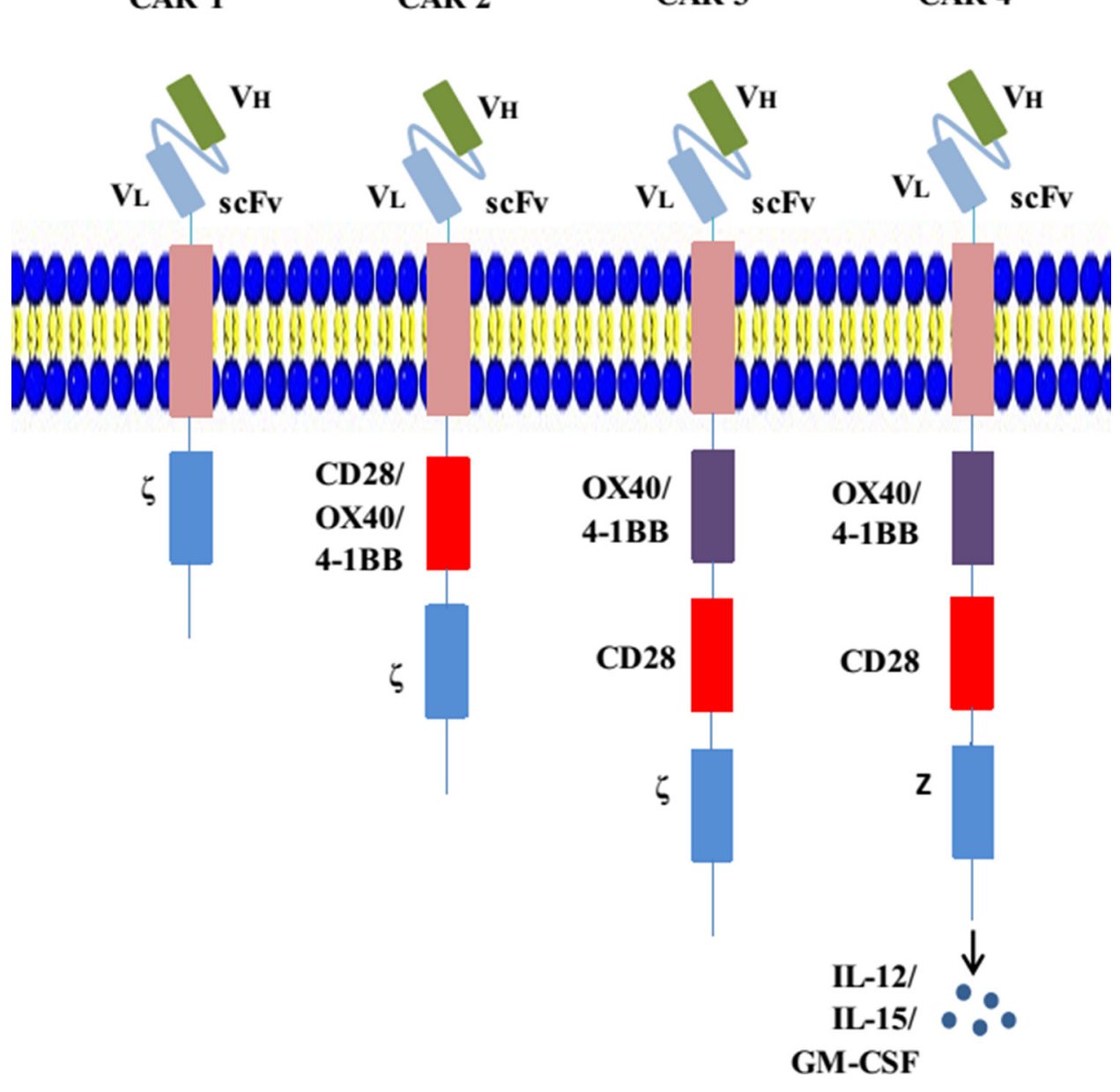

Figure 1: Evolution of CARs. CAR $1^{\circ}$ represents the first-generation CARs; an scFv links the CD3 $\zeta$ or FceRI $\gamma$ in the transmembrane region. CAR $2^{\circ}$ represents the second-generation CARs; costimulatory molecules such as CD28 are engineered to the signal-transduction region. CAR $3^{\circ}$ represents the third-generation CARs; they contain two costimulatory domains. CAR $4^{\circ}$ (also called TRUCK) represents the fourth-generation CARs; they are additionally modified using a constitutive or inducible expression cassette for a transgenic protein (e.g., a cytokine), which is released by the CAR-T-cell to modulate T-cell response. 
cells have demonstrated that they engaged their target antigens and are generally safe, the infused CAR-T cells exhibited short persistence and minimal efficacy $[19,20]$. To improve the persistence of CAR-T-cell cytotoxicity, second-generation CAR-T cells have been designed on the basis of primal generation with the addition of one intracellular costimulatory domain, including the CD28 molecule or members of the tumor necrosis factor receptor family such as CD27, 4-1BB (CD137), and OX-40, which was discovered to increase the resultant persistence and cytotoxicity [21-23]. Receptors containing both $\mathrm{CD} 3 \zeta$ and $\mathrm{CD} 28$ (or CD27, 4-1BB, or OX-40) are the prototypes for second-generation CAR-T cells, which are currently being rapidly expanded to various arrays of receptors with diverse functional properties. More recently, third-generation CARs (triple-fusion receptors) comprising $\mathrm{CD} 3 \zeta$ and two costimulatory molecules have been developed, which further enhance cytotoxicity durability compared with dual-fusion receptors [24, 25]. Newly generated fourth-generation CARs, also named TRUCK T cells, were engineered to produce cytokines, particularly interleukin (IL)-12, which can regulate the antitumor microenvironment. IL-15 and granulocyte-macrophage colony-stimulating factor (GM-CSF) also contribute to this strategy [16]. A more recent study, which generated allogeneic universal $\mathrm{T}$ cells deficient of both programmed death 1 (PD-1) and cytotoxic T-lymphocyte antigen (CTLA-4) pathways (inhibitory pathways for immune escape), was attempted using human lymphocytes in vitro [26]. Moreover, a double-antigen CAR-T was also proposed and applied in an animal model to reduce CAR-T-related toxicities [27].

\section{CAR CONSTRUCT TRANSDUCTION: VIRAL AND NONVIRAL APPROACHES}

Various genetic methods are used to transfer a specific gene into mouse or human $\mathrm{T}$ lymphocytes. These methods, including viral and nonviral methods, differ in the expression levels and stability of the modified CAR-T cells. This paper describes frequently used viral approaches - gamma retroviral, lentiviral, adenovirus, and adeno-associated viral vectors-as well as nonviral approaches such as liposomal-mediated gene transfer, messenger RNA-mediated gene transduction and Sleeping Beauty transposon/transposase system. (Table 1).

\section{Viral approaches}

\section{Retroviral vectors (RVs)}

In general, viral vectors are more efficient at delivering target genes to cells than physical methods such as direct DNA injection and gene gun technology [28]. The ability of RVs to successfully deliver foreign genes was first reported in 1981 [29]. In OC, the gene therapy approach initially employed was the use of recombinant
RVs [30, 31]. RVs are lipid-enveloped particles containing two identical copies of a linear single-stranded RNA genome of length approximately $7-11 \mathrm{~kb}$ [32]. The viral protein genes (gag, pol, and env) are removed from retroviruses during the development of the gene delivery carrier. Substitutability and integration are the two principal features of retroviruses. Substitutability refers to the ability for a majority of the retroviral genome to be replaced with a transgene of interest. Integration refers to the permanent integration of the retroviral transgene into the host's genome during cell division [33]. RVs are promising stable and efficient gene transfer systems and are generally employed in OC therapy [34, 35]. However, large-scale use of RVs in clinical practice still involves challenges such as insertional mutagenesis and high titer vector production, which may cause cellular immortalization and neoplastic transformation [36]. Moreover, most of the retroviruses infect only actively dividing cells during cell mitosis [37]. Although this feature may protect normal cells, tumor tissues also contain nondividing cells in the G0 phase. Such cells may escape from the therapy. Therefore, improving vector designs, selecting appropriate cancer types, and elucidating tumor cell biology are crucial issues that must be addressed before the extensive application of RVs in clinics.

\section{Lentiviral vectors (LVs)}

LVs, although sharing many features with RVs derived from oncogenic retroviruses, can also transduce some resting cells in vivo; this is because they can pass through intact host nuclear membranes and do not need cell division for integration [28, 38, 39]. This enables LV transduction in a wide range of cells including both dividing and nondividing cells. LVs integrate into the target cell genome stably, leading to the lasting expression of the gene of interest. In an OC model, LVs greatly outperformed RVs in growth-arrested cell transduction, and the transfection efficiency of LVs in OC cells was 10 times higher than that of RVs [39]. This was an expected and important finding because that study was the first to confirm that LVs can infect nonproliferating cells among growth-arrested OC cells. The genomic integration sites of LVs are not related to promoter regions, which can decrease the risk of meaningful insertional mutagenesis $[33,40]$. All the aforementioned features render LV systems safer and more efficient for CAR expression and application in cancer immunotherapy. Several applications that use modified CAR-T cells with LV systems are being developed to treat OC $[41,42]$ and achieve active results.

\section{Adenoviruses}

Adenoviruses are double-stranded DNA viruses that infect both dividing and nondividing cells and can cause a wide range of benign respiratory infections in humans [43, 44]. Defective-competent adenoviral vectors (AVs) were first established by replacing the viral E1 gene with a therapeutic gene. Subsequently, more valid gene carriers 
Table 1: Frequently used approaches to transduction in tumors

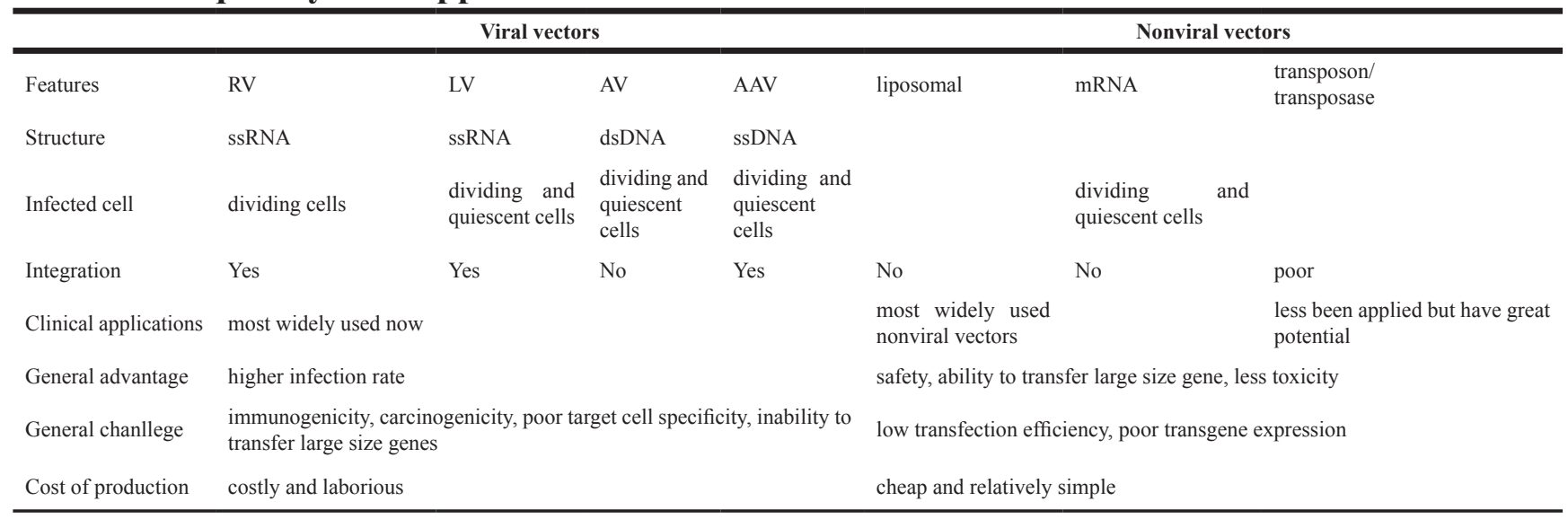

AAV, adeno-associated virus vector; AV, adenovirus vector; dsDNA, double-stranded deoxyribonucleic acid; LV, lentiviral vector; mRNA, messenger ribonucleic acid; RV, retroviral vector; ssDNA, single-stranded deoxyribonucleic acid; ssRNA, single-stranded ribonucleic acid.

were produced by altering more genes in the viral genome, such as the E2 gene [45]. AVs have been extensively used in cancer immunotherapy and successfully developed for selective tumor gene therapy in OC [46-48]. One study reported transfection using AVs to be transient because the adenoviral DNA genome does not integrate into the host genetic material permanently [49]. Therefore, repetitive administration of $\mathrm{AVs}$ is required to obtain the desired therapeutic outcome. To overcome the low infection rate of AVs, researchers have explored a class of infectiveenhanced AVs-consisting of coxsackie-adenovirus receptor-independent targeting motifs RGD (Ad5.RGD), polylysine (Ad5.pK7), or both (Ad5.RGD.pK7) - for their use in OC gene therapy. These AVs were found to infect OC cell lines with substantially enhanced infectivity. Among the developed AVs, Ad5.RGD.pK7 exhibited the highest efficacy in a subcutaneous tumor model [50].

\section{Adeno-associated viral vectors (AAVs)}

An AAV is a nonpathogenic, single-stranded DNA parvovirus with an inverted terminal repeat (ITR) on the end of each single-stranded DNA genome. An ITR is the only cis-acting element required for genome replication and packaging [51]. As a dependovirus, an AAV carries two viral genes, rep and cap, which are removed in gene therapy. An AAV can infect both dividing cells and quiescent cells [52]. Emerging recombinant AAV (rAAV) gene delivery vectors are produced by deleting the two viral genes rep and cap and inserting a transgene expression cassette between the two ITRs. Therefore, rAAVs have minimal associated toxicity, which makes them potential tools for delivering a vast range of appropriate transgenes in numerous disease models. Kringle 5 (K5) of human plasminogen is one of the most potent angiogenesis inhibitors. A study investigating the antitumor effects of rAAV-mediated delivery of humanOC-cell K5 gene (a angiogenesis inhibitor) in mouse models reported that a single injection of AAV-K5 inhibited both subcutaneous and intraperitoneal growth of human OC cells [53]. A similar study indicated that an antiangiogenic gene in combination with an rAAV can be used to treat OC growth and dissemination [54]. When evaluating the successful therapeutic outcomes of a gene delivery vector, long-term gene expression and infection efficiency should not be neglected. In addition, when investigating the tremendous potential of $\mathrm{AAVs}$ for efficient gene delivery, limiting factors such as internalization, endosomal trafficking, and nuclear import should be considered.

\section{Nonviral approaches}

To address the limitations of viral vectors, such as their safety and the capacity of their transgenic materials, researchers have been encouraged to focus on investigating nonviral vectors as an alternative. In contrast to viral vectors, nonviral systems are easy to produce and have a much lower risk of inflammatory complications [55].

\section{Liposome-mediated gene transfer}

Lipid-based vectors are the most extensively used nonviral gene carriers. In 1980, a study first demonstrated that liposomes composed of the phospholipid phosphatidylserine entrapped and delivered SV40 DNA to monkey kidney cells [56]. Yu et al. [57] revealed that liposome-mediated E1A gene transfer substantially suppressed the growth and dissemination of OC cells that overexpressed HER2/neu in mice. Most of (approximately 70\%) these mice survived for more than 365 days, whereas all the mice in the control group, which did not receive the liposome-mediated gene therapy, died within 160 days. This result reveals that liposome-mediated E1A transduction may be a valid immunotherapy approach for human OCs that overexpress HER-2/neu. Cationic lipids are currently widely used for liposomal gene transfer because of their extraordinary potential to condense DNA $[58,59]$. In ovarian adenocarcinoma, the cationic liposome DDC 
[a combination of dioleoyltrimethylaminopropane (DOTAP), 1,2-dioleoyl-3-phosphatidylethanolamine, and cholesterol] is a promising nonviral vector because of its selective high gene transfer ability [60]. Various liposomal formulations have been employed, including DOTAP [61], dioctadecylamidoglycylspermine, and dipalmitoyl phosphatidylethanolamidospermine [62]. Cationic liposomes have been explored in vitro, in vivo, and also in clinical patients [63]; however, the main difficulty that remains to be resolved is the low transfection efficiency for clinical applications.

\section{Messenger RNA (mRNA)-mediated gene transduction}

In vitro-transcribed mRNA-mediated gene delivery has gained special popularity as an alternative to DNAbased nonviral and viral gene transduction methods. An mRNA CAR delivery system does not incur the risk of insertional mutation or potential malignant transformation/genotoxicity of transduced cells compared with viral transduction, which can integrate into the host genome [64]. Moreover, mRNA gene transduction can be used to transduce both quiescent and proliferating cells. A study revealed that transduced CAR-T cells often cause ontarget, off-tumor effects in normal tissue because of their ability to achieve stable and prolonged expression [65]. An mRNA delivery system is characterized by transient CAR expression; thus, on-target, off-tumor side effects are selflimited as the RNA CAR degrades. Data have revealed that in an mRNA induction system, the autologous $\mathrm{T}$ cells are enriched, expanded, and active for 8-12 days $[66,67]$. In several cancer types such as mesothelioma and acute myeloid leukemia, mRNA-transduced CAR-T cells have been reported to generate the expected antitumor effects at both primary and metastatic sites [66, 68].

\section{Sleeping Beauty (SB) transposon/transposase system}

The SB transposon/transposase system is another nonviral approach and has been employed in clinical practice to stably insert a CAR to redirect T-cell specificity [69]. The transposon/transposase system has two components: a plasmid carrying the gene of interest (transposon) and another plasmid encoding the transposase [70]. As gene therapy vectors, transposons were found to have two advantages over viruses: first, clinical manufacture and quality control are easier, cheaper, and more reliable when viruses are employed. Second, unlike viral cargos, which are usually integrated into genes that can incur mutagenic risks, these SB transposons have few known preferences for integration sites [71]. The transposase can recognize the inverted repeat containing direct repeated sequences flanking the transgene (e.g., CAR) in a transposon [72]. The SB transposon is now employed in clinical practice and has exhibited promising antitumor efficiency [69]. To further enhance the transfection efficiency of the SB system, several new transposases such as SB10, SB11, and SB100X have been used in studies to deliver various genes into different cells [73].
In addition to vector systems, emerging genome editing technologies are also required for successful CAR-Ts immunotherapy. To date, four major platforms have been exploited for these site-specific DNA-editing purposes: meganucleases, zinc finger nucleases, transcription activatorlike effector-nucleases, and most recently the clustered regularly interspaced short palindromic repeats (CRISPR/ Cas) system [74].

\section{RATIONALITY OF CAR-T CELLS THERAPY IN OC}

CAR-T cells combine both antigen specificity and T-lymphocyte activation properties in a single fusion molecule. During the past decade, CARs have demonstrated remarkable effects on patients with hematological tumors $[75,76]$. Using them to target solid tumors, however, is challenging, probably because of features in their histopathological structure and their difficulty in T-cell trafficking and T-cell infiltration into tumor sites [77]. Solid tumors have special histopathological features, including poor integrity of issue structure, a high concentration of blood vessels, and extensive vascular leakage. These features induce selectively enhanced permeability and retention (EPR) of lipid particles and macromolecular substances in solid tumors. Effector T lymphocytes play critical roles in the success of T-cell-based immunotherapy. The EPR effect in a solid tumor microenvironment can impede the infiltration of effector T lymphocytes into tumor tissues [78]. Aberrant vasculature, the downregulation of adhesion molecules, and the mismatch of chemokine-chemokine receptor pairs may also lead to the poor homing of T lymphocytes [79]. Heterogeneity is a prominent feature of many types of solid tumor and causes specific CAR-Ts to become effective in only a portion of tumor cells [78]. Therefore, the most advantageous way to treat solid tumors using CAR-Ts is to identify the specific cell surface antigens. Furthermore, the immunosuppressive environment within a solid tumor also causes difficulties in the use of CAR-Ts. A hypoxic, low $\mathrm{pH}$ intrinsic microenvironment and the activated inhibitory pathways can induce or enhance immunosuppression within tumor sites [80]. Despite the several challenges to applying CAR-Ts to solid tumors, numerous CARs targeting diverse cancer types including $\mathrm{OC}$ have been developed [41, 81, 82]. Although clinical pilot trials have just begun in OC, the potential of this form of CAR-T-cell immunotherapy is becoming increasingly evident.

OCs are immunogenic tumors, and OC immunotherapies have demonstrated considerable potential for treating patients with such tumors [83]. The first and crucial evidence confirming the rationality of immunotherapy for $\mathrm{OC}$ was presented by a study revealing that $\mathrm{CD3}^{+}$tumor-infiltrating $\mathrm{T}$ lymphocytes (TILs) were correlated with patients' increased overall survival (OS) and progression-free survival [84]. The administration 
of autologous TILs to patients with OC after surgery and chemotherapy resulted in increased objective regression, prolonged disease-free survival (DFS), and improved survival rate, supporting that T-cell transfer therapy actively inhibits OC cell growth [7, 8]. A study on tumor microenvironments demonstrated that $\mathrm{CD}^{+}$and $\mathrm{CD}^{+} \mathrm{T}$ lymphocytes were vital antitumor effectors in OC [85]. By contrast, an increased number of $\mathrm{CD} 4^{+} \mathrm{CD} 25^{+} \mathrm{FoxP}^{+}$ regulatory $\mathrm{T}$ cells in the $\mathrm{OC}$ microenvironment has been demonstrated to predict chemoresistance and poor prognosis [86, 87]. Furthermore, solid tumors often employ multiple mechanisms to attenuate the validity of T-lymphocyte-mediated attacks by in turn downregulating MHC class I (MHC-I) or other molecules related to the antigen-processing machinery in order to evade immune responses [88]. The downregulation of MHC-I on the surface of a cancer cell restrains the homing of $\mathrm{T}$ lymphocytes because the interaction between the TCR and peptide-MHC is a prerequisite for T-lymphocyte activation [89]. Nevertheless, CARs bypass the immune escape mechanism of cancer cells because they endow $\mathrm{T}$ lymphocytes with cytotoxic effector features in an MHCunrestrictive manner [90]. This is particularly important for $\mathrm{OC}$, in which the advanced stage is correlated with $\mathrm{MHC}$ downregulation [91]. These findings imply that patients with OC may benefit from CAR-T cells in clinical practice.

\section{ACTIVE CAR-T CELL THERAPY IN OC}

Human $\mathrm{T}$ lymphocytes modified with synthetic receptors can redirect tumor antigens specifically and present striking efficacy in numerous human malignant tumors [92]. In addition, CAR-T cells targeting diverse tumor-associated antigens have already been developed, characterized, tested, and reported [93]. The cell surface antigens targeted by CARs include proteins, carbohydrates, and glycolipids [94]. The most common antigens targeted by CARs in OC include MUC16, folate receptor- $\alpha(\mathrm{FR} \alpha)$, mesothelin, and HER2 (Table 2).

\section{MUC16 ecto}

Mucins are vital biomolecules in cellular homeostasis and epithelial surface protection. MUC16 is a highly glycosylated mucin; it is overexpressed in most OCs and is an established surrogate blood biomarker (CA-125) for the diagnosis and progression of OCs $[95,96]$. The full length of MUC16 comprises a large cleaved and released domain termed CA-125, which contains multiple repeat sequences; a conserved domain called MUC16 ecto, which contains a residual nonrepeating extracellular fragment; a transmembrane domain; and a cytoplasmic tail including a phosphorylation site (Figure 2) [97, 98]. A previous study suggested that MUC16 plays a role in OC cell metastasis, forming implants on the surface of the peritoneal cavity [99]. A hybridoma that generates an antibody specific to the extracellular conserved domain MUC16 ecto was used to produce a CAR specific to MUC16 ecto (4H11-28z); this CAR was then referenced to engineer autologous $\mathrm{T}$ lymphocytes targeted at a surface-exposed, retained antigen [10].

CAR-modified MUC16-target T lymphocytes have high MUC16-specific cytotoxic activity against OC cells in vitro. In addition, the infusion of expanded 4H11-28zexpressed $\mathrm{T}$ lymphocytes through intravenous infusion or intraperitoneal injection into mice bearing human MUC16+ ovarian tumors was discovered to either delay progression or completely eradicate tumors [100]. These investigational preclinical studies justify the in-depth investigation of MUC16-targeted T lymphocytes as a potential therapeutic strategy for patients with OC using high-risk MUC16+ tumor cells. Currently, a dose-escalation phase I trial using IL-12-secreting MUC16 ecto-directed CAR-T cells for recurrent $\mathrm{OC}$ is ongoing [10].

\section{Folate receptor- $\alpha(\mathrm{FR} \alpha)$}

$\mathrm{FR} \alpha$ is a glycosylphosphatidylinositol-anchored protein that is overexpressed on the surface of epithelial tumors including breast, ovary, lung, colorectum, brain, and other solid malignant tumors, but the expression of which is limited in normal tissues [101]. A membranebound protein, FR $\alpha$ recognizes folic acid with high affinity and specifically mediates the cellular uptake of folic acid (and drug conjugates thereof) through receptor-mediated endocytosis [102]. Overexpression of $F R \alpha$ is related to high-grade cancer progression, poor prognosis in OC [103], and short survival rates in breast cancer [104]. Therefore, FR $\alpha$ is a potential candidate for targeted immunotherapy of epithelial-derived malignancies, particularly for epithelial OC (EOC), in which nearly $90 \%$ of tumor cells express FR $\alpha$ [105].

Human $\mathrm{T}$ cells modified to express CARs specific for FR $\alpha$ have been reported to exhibit effective antitumor activity in vitro and in animal models; however, their effects on clinic patients appear to be weak due to their inability to persist and home in on tumor sites $[11,106]$. In 2006, the use of genetically redirected CAR-T cells for the treatment of $\mathrm{FR} \alpha^{+} \mathrm{OC}$ was first reported in a clinical trial [107]. In this trial, no tumor burden reduction was observed in any patient with OC. Polymerase chain reaction analysis revealed that modified $\mathrm{T}$ cells were present in the circulation in large numbers for the first 2 days after transfer; however, their number rapidly declined and the modified T cells were barely detectable after 1 month in most patients. The study concluded that a large number of gene-modified tumor-reactive $\mathrm{T}$ cells can be safely given to patients, but these $\mathrm{T}$ cells do not persist for a long period [107]. Another study constructed CAR-T cells containing the FR $\alpha$-specific scFv MOv19 coupled to the $\mathrm{CD} 3 \zeta$ chain signaling module alone (MOv19- $\zeta$ ) or in combination with the costimulatory motif CD137 (4-1BB) 
Table 2: Active clinical trials of CAR-T immunotherapies for ovarian cancer*

\begin{tabular}{|c|c|c|c|c|c|c|}
\hline Target antigen & $\begin{array}{l}\text { Receptor type } \\
\text { (other specificity) }\end{array}$ & $\begin{array}{l}\text { Gene transfer } \\
\text { vehicle }\end{array}$ & NCT & Phase & Sponsor & Indication \\
\hline MUC16 & $\begin{array}{l}4 \mathrm{H} 11-28 \mathrm{z} / \\
\text { fIL-12/ } \\
\text { EFGRt }\end{array}$ & RVs & 02498912 & I & $\begin{array}{l}\text { Memorial Sloan } \\
\text { Kettering Cancer Center }\end{array}$ & $\begin{array}{c}\text { Recurrent } \\
\text { MUC16ecto }{ }^{+} \text {solid tumors }\end{array}$ \\
\hline \multirow[t]{3}{*}{$\alpha$-Folate receptor } & n.p. & RVs & 00019136 & I & $\mathrm{NCI}$ & Advanced EOC \\
\hline & $\begin{array}{l}\text { ScFV- } \\
4-1 B B- \\
\text { CD3 }\end{array}$ & LVs & 02159716 & I & University of Pennsylvania & $\begin{array}{l}\text { Patients with mesothelin expressing } \\
\text { cancers }\end{array}$ \\
\hline & n.p. & LVs & 03054298 & I & University of Pennsylvania & $\begin{array}{l}\text { Patients with mesothelin expressing } \\
\text { cancers }\end{array}$ \\
\hline \multirow[t]{2}{*}{ Mesothelin } & $\begin{array}{l}\text { ScFV- } \\
\text { CD3 } 5- \\
\text { CD137 }\end{array}$ & RVs & 02580747 & I & Chinese PLA General Hospital & $\begin{array}{l}\text { Relapsed and/or chemotherapy refractory } \\
\text { malignancies }\end{array}$ \\
\hline & n.p. & RVs & 01583686 & $\mathrm{I}, \mathrm{II}$ & National Cancer Institute(NCI) & $\begin{array}{l}\text { Metastatic cancer expressing the } \\
\text { mesothelin molecule }\end{array}$ \\
\hline \multirow[t]{2}{*}{ HER2 } & $\begin{array}{l}\text { ScFV- } \\
\text { CD3 }- \\
\text { CD137 }\end{array}$ & n.p. & 01935843 & I, II & Chinese PLA General Hospital & $\begin{array}{c}\text { Chemotherapy refractory HER2+ } \\
\text { advanced solid tumors }\end{array}$ \\
\hline & n.p. & n.p. & 02713984 & I, II & Zhi Yang & $\mathrm{HER}^{+}$cancer \\
\hline EGFR & $\begin{array}{l}\text { ScFV- } \\
\text { CD3ל- } \\
\text { CD137 }\end{array}$ & LVs & 01869166 & I, II & Chinese PLA General Hospital & $\begin{array}{l}\text { Chemotherapy refractory EGFR } \\
\text { advanced solid tumors }\end{array}$ \\
\hline CD133 & $\begin{array}{l}\text { ScFV- } \\
\text { CD3 }- \\
\text { CD137 }\end{array}$ & RVs & 02541370 & I & Chinese PLA General Hospital & $\begin{array}{c}\text { Relapsed and/or chemotherapy refractory } \\
\text { advanced } \\
\text { malignancies }\end{array}$ \\
\hline CEA & n.p. & RVs & 01212887 & I & Cancer Research UK & $\begin{array}{l}\text { Patients with advanced CEA } \\
\text { positive tumors }\end{array}$ \\
\hline NKG2D & n.p. & n.p. & 03018405 & I & Celyad & Various tumors expressing NKR-2 \\
\hline NY-ESO-1 & n.p. & RVs & 02366546 & I & Mie University & $\begin{array}{l}\text { Unresectable, refractory solid tumors } \\
\text { expressing NY-ESO-1 }\end{array}$ \\
\hline MAGE-A4 & n.p. & RVs & 02096614 & I & Mie University & $\begin{array}{l}\text { Unresectable, refractory, metastatic or } \\
\text { recurrent tumors expressing MAGE-A4 }\end{array}$ \\
\hline WT-1 & n.p. & n.p. & 00562640 & I & $\begin{array}{c}\text { Memorial Sloan } \\
\text { Kettering Cancer Center }\end{array}$ & Recurrent or persistent advanced EOC \\
\hline
\end{tabular}

*ClinicalTrials.gov

EOC, epithelial ovarian cancer; LVs, lentiviral vectors; NCI, National Cancer Institute; n.p., not provided; RVs, retroviral vectors.

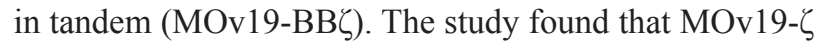
or costimulated MOv19-BB $\zeta$ CAR-T cells secreted diverse proinflammatory cytokines such as interferon (IFN)- $\gamma$, IL-2, TNF- $\alpha$, IL-4, and IL-10 and exerted their cytotoxic function when cocultured with $\mathrm{FR} \alpha+\mathrm{OC}$ cells in vitro. However, only costimulated MOv19-BBל CAR-T cells mediated tumor regression in immunodeficient mice with large, established FR $\alpha+$ human OC [11]. Moreover, MOv19-BB $\zeta$ CAR-T cells mediated tumor regression in models of metastatic intraperitoneal, subcutaneous, and lung-involved human OC [11]. The study overcame the weaknesses of previous CAR approaches by increasing the persistence of modified $\mathrm{T}$ cells in vivo, in addition to enhancing the accumulation of the cells at tumor sites and their antitumor potency.

\section{Mesothelin}

Mesothelin is so named because of its expression in mesothelial cells [108]. This membrane glycoprotein is glycosylphosphatidylinositol-linked and is overexpressed on the surface of mesothelioma and OC cells as well as in malignancies of the lung, pancreas, and stomach [108-110]. Mesothelin originates from the precursor mesothelin protein, which is cleaved by a furin-like protease, and it is also referred to as C-ERC/mesothelin [111]. Compared with its low expression level in normal tissues, mesothelin is a promising target for the treatment of OC because it is expressed in $82 \%$ of serous epithelial OC cells [112]. The function of mesothelin is still not completely understood; however, mesothelin binds to CA125, suggesting that mesothelin may contribute to the peritoneal and pleural metastasis of OC [113]. In addition, one study demonstrated that mesothelin overexpression is related to chemoresistance, shorter DFS, and poor OS in patients with epithelial OC [114].

In an animal model, lentiviral CAR-T-mesothelin cells injected into mice intratumorally or intravenously led to a marked decrease in tumor size or eradication of tumors in mesothelin-expressing OC and mesothelioma [115]. In addition, a fully human antimesothelin $\mathrm{scFv} \mathrm{P} 4$ was reported in a preclinical model. Primary human $\mathrm{T}$ cells expressing P4 CAR specifically produced proinflammatory cytokines (including IFN- $\gamma$, macrophage inflammatory protein- $1 \alpha$, TNF- $\alpha$, and IL-2) and degranulated and exerted potent cytolytic functions when cultured with mesothelin-expressing tumors in vitro in a xenogenic model of human OC [42]. A phase I clinical 
trial of CAR-T directed against mesothelin was conducted (NCT02159716), and the preliminary results revealed that an infusion of CAR-mesothelin T cells was well tolerated without an off-tumor effect or cytokine release syndrome (CRS) in patients with mesothelioma, OC, and pancreatic cancer. Currently, numerous clinical trials evaluating diverse mesothelin-directed CARs (NCT03054298, NCT02580747, NCT01583686) are ongoing.

\section{HER2}

The HER2 oncogene (also known as ERBB2 or neu) is located in the long arm of chromosome 17 and belongs to the epidermal growth factor receptor family [116]. The HER2 protein (185 $\mathrm{kDa})$ is encoded by the HER2 proto-oncogene and is involved in the development and progression of OC [117]. This protein consists of a large extracellular domain, a hydrophobic transmembrane domain, and an intracellular domain with an ATP-binding tyrosine kinase domain and a carboxy-terminal domain [118]. HER2 has been demonstrated to be expressed in approximately $40 \%$ of EOCs, as evaluated using immunohistochemistry, and its overexpression has been reported to be associated with poor prognosis in breast cancer, OC, and many other malignancies [117, 119-121]. Since the 1980s, academic laboratories have been increasingly producing monoclonal antibodies to target HER2 [119]. The development and application of Trastuzumab (Herceptin) $\mathrm{mAb}$ treatment represented a paradigm shift from nonspecific chemotherapy to molecularly targeted therapy in oncology. However, Trastuzumab is expensive and can cause side effects including cardiotoxicity, corneal ulceration, and neutropenia; hence, its use is limited [122-124]. Currently, HER2-specific CAR-T cells have been applied in preclinical studies. A study developed a novel, humanized HER2 CAR that contains a chA21 scFv region of antigen-specific $\mathrm{mAb}$ and $\mathrm{T}$-cell intracellular signaling chains composed of CD28 and CD3 $\zeta$ in tumorbearing mice. Results revealed that the novel chA21 scFvbased, HER2-specific CAR-T cells recognized and killed HER2+ breast and OC cells ex vivo [125]. In a glioblastoma model, tandem CAR-T cells targeting HER2 and IL13R $\alpha 2$ were discovered to mitigate tumor antigen escape, exhibit enhanced antitumor efficacy, and improve animal survival [126]. To date, clinical trials of HER2-specific CAR-T-cell therapy in OC have been rare. Ongoing clinical trials are listed in Table 2.

\section{CAR-RELATED TOXICITIES}

Despite its potential and promising clinical results, CAR-T-cell immunotherapy involves several toxicities because of the presentation of tumor-associated antigens by healthy tissues and the inability to control T-cell activity. The prominent toxicities of CAR-T-cell immunotherapy are CRS and on-target, off-tumor toxicities.

The CRS effect (so-called cytokine-associated toxicity) is caused by intense tumor-killing actions mediated by numerous activated lymphocytes (B cells, T cells, and NK cells) [127]. The extremely high levels of cytokines such as C-reactive protein, IL-6, and IFN- $\gamma$ observed in human bodies with cancer are several hundred times higher than the baseline levels, and such

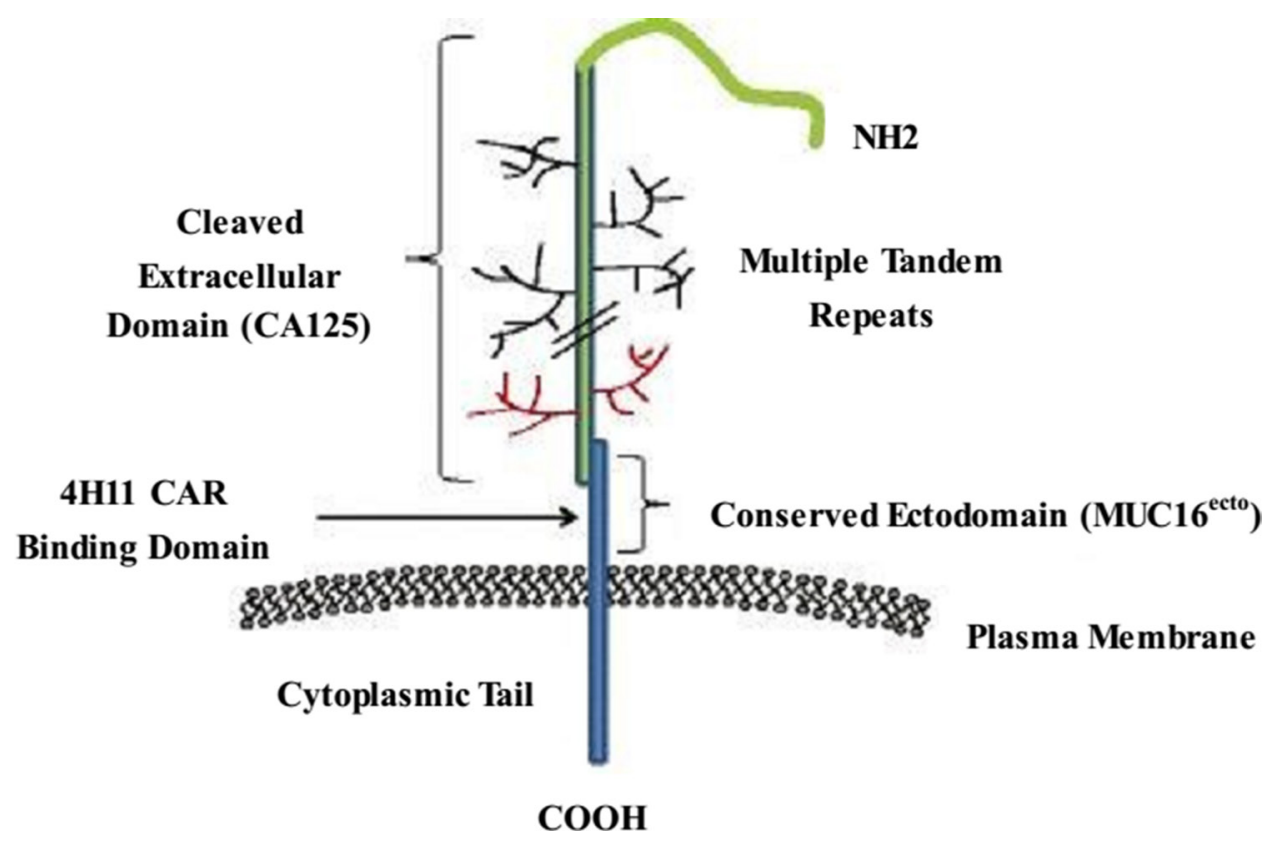

Figure 2: Schematic of MUC16 structure. The full-length MUC16 contains a large cleaved and released domain named CA125 consisting of multiple repeat sequences, followed by a conserved cytoplasmic domain MUC16 $6^{\text {ecto }}$ including a nonrepeating ectodomain, a transmembrane domain, and a cytoplasmic tail. 
high levels typically cause clinical syndromes including hypotension, fever, and neurological changes and can even lead to sudden death. In clinical practice, gynecological oncologists reported CRS in a 52-year-old woman with OC who had received treatment using autologous mesothelin-redirected CAR-T cells (CART-meso). Highvolume production of pleural fluid was evident after T-cell infusion, with a higher number of CART-meso cells in the pleural cavity compared with that in the blood, as well as a greater increase in IL-6 within the pleural fluid [128]. To enable assessment of the severity of CRS, Lee et al. published a grading system containing five grades that is based on the clinical signs and symptoms of CRS [129].

One previous study demonstrated that tumorassociated antigens were expressed not only in tumor cells but also in normal cells [130]. When tumor-associated antigens are used as targeting molecules for CAR-T-cell therapies, normal cells can also be distinguished and attacked by lymphocytes, causing damage to normal tissue (referred to as on-target, off-tumor toxicity). This type of on-target toxicity leads to rapid cardiopulmonary toxicity and can even be life-threatening. A case report detailed a serious "on-target" adverse event following the application of $\mathrm{T}$ cells transduced using a CAR recognizing ERBB2. A 39-year-old woman with colon cancer metastatic to the lungs and liver experienced respiratory distress, and a drastic pulmonary infiltrate was identified on a chest X-ray after CAR-T-cell therapy. She was intubated, and despite intensive medical intervention, she died 5 days after treatment. The death of this patient was speculated to be a result of the infusion of highly active anti-ERBB2-directed CAR-T cells, which recognized ERBB2 expressed by normal lung epithelial cells and released inflammatory cytokines (TNF- $\alpha$ and IFN- $\gamma$ ) that caused pulmonary toxicity and multiorgan failure [131].

Although CAR-T therapy involves toxicities when used to treat solid tumors including $\mathrm{OC}$, these toxicities are generally much weaker than those when blood cancers are the target. Because immunity in a solid tumor is more restricted to a local site, the T-cell trafficking and infiltration into tumor sites is more difficult, and T-cell functions are inhibited in cancer microenvironments by proteins or immunosuppressive cells [77]. In addition, great attention must be paid to CAR-T related toxicities in solid tumors because of the risk of mortality they incur.

\section{SOLUTIONS FOR THE MITIGATION OF CAR-RELATED TOXICITIES}

To mitigate CAR-related toxicities, several methods have been developed either in OC or other malignancies. Herein, we discuss common solutions for CAR-related toxicities applied to solid tumors including OC and detail innovative approaches that can indicate some future research directions for its treatment of OC. In clinical practice, to moderate the immunotoxicities caused by therapeutic CAR-Ts, exogenous inhibitors with cytostatic or cytotoxic effects such as corticosteroids and cytokine blockades (tocilizumab and etanercept) were successfully used to ameliorate CRS $[132,133]$. To reduce on-target, off-tumor toxicity, a safe, effective, and widely used method of improving safety and efficacy is to incorporate a regulated suicide gene into engineered CAR-T cells, such as the HSV-TK [134] and iCasp9 [135] suicide genes. An ideal suicide gene, which should eliminate CAR-T cells, should be stably coexpressed in the modified cells in addition to being in sufficiently high levels to elicit cell death. Therefore, a suicide gene should exhibit high specific activity and low susceptibility to endogenous antiapoptotic molecules. Ad5.SSTR/TK.RGD is an infectivity-enhanced adenovirus expressing a therapeutic thymidine kinase suicide gene and a somatostatin receptor. One study demonstrated the feasibility, safety, and potential clinical efficacy of suicide gene therapy by using Ad5.SSTR/TK.RGD in OC [136]. CTLA-4, PD-1 immune inhibitory receptors, and inhibitory-CAR-engineered $\mathrm{T}$ cells edited using a system with CRISPR may also have similar effects [26]. Furthermore, to overcome potential on-target, off-tumor adverse events, identifying genuine tumor-specific targets is imperative. An emerging method of improving the safety of CAR-T cells is the use of a dual-antigen receptor, which involves the coexpression of two different antigen receptors to target two different tumor antigens [137]. CAR-T cells with dual-antigen receptors have been reported to have high specificity and accuracy and to induce less intense side effects. Moreover, identification of appropriate and specific tumor-associated antigens expressed only in cancer cell membranes, but not in normal cells, is imperative. In addition, oxygen-sensitive CAR-T cells, which can restrict the immune response to tumor tissue, are safer because they minimize on-target, off-tumor effects. As mentioned, tumor microenvironments have been associated with hypoxia. Juillerat et al. [138] generated CAR-Ts that were responsive to an hypoxic environment by fusing an oxygen-sensitive subdomain of HIF $1 \alpha$ to a CAR scaffold. They discovered that increased surface expression of HIFCARs along with improved cytolytic properties of $\mathrm{T}$ cells can be obtained under hypoxic conditions.

\section{DISCUSSIONS AND CONCLUSIONS}

CAR-T cells have two major advantages compared with TCR-T cells: (1) MHC-independent recognition of tumor-associated antigens, which enables the extensive application of CARs irrespective of the patient's MHC and the successful recognition of cancer cells with downregulated MHC expression, and (2) extremely low risk of mispairing with TCRs endogenously. CAR-T cells are therefore not just an alternative but may prove to be superior to TCRs as a therapeutic strategy. The use of CAR-T cells in cancer immunotherapy is currently 
coming of age. As previously mentioned in our description of the clinical application of CAR-T-cell immunotherapy in OCs, CAR-T-cell immunotherapy is an appealing area of OC research, expands the spectrum of antitumor strategies, and has both clinical and economic value. Increasing numbers of clinical trials are being performed to verify its safety and efficacy in OCs (NCT02159716, NCT03054298, NCT02580747, and NCT01583686). Moreover, various combinations of CARs with TCRs are promising, achieving greater persistence and response. However, the potential side effects and cytotoxicities including the CRS effect and "on-target" adverse events must still be considered and resolved before this novel and promising approach can be broadly applied to treat patients with OC. Furthermore, a thorough understanding of the molecular mechanisms during the design, processing, and implementation steps is crucial to improve the safety and efficacy of CAR-T cell immunotherapy.

\section{Ethical approval}

This article does not contain any studies with human participants or animals that were performed by any of the authors.

\section{Author contributions}

Xinxin Zhu contributed to data collection, content discussions, and the writing of the manuscript. Han Cai, Ling Zhao, Li Ning contributed to the writing of the manuscript. Jinghe Lang designed the study and reviewed the article.

\section{ACKNOWLEDGMENTS} article.

There was no financial support or funding for this

\section{CONFLICTS OF INTEREST}

No potential conflicts of interest relevant to this article is reported.

\section{REFERENCES}

1. Siegel RL, Miller KD, Jemal A. Cancer statistics, 2015. CA Cancer J Clin. 2015; 65:5-29.

2. Dinh P, Harnett P, Piccart-Gebhart MJ, Awada A. New therapies for ovarian cancer: cytotoxics and molecularly targeted agents. Crit Rev Oncol Hematol. 2008; 67:103-12.

3. Bookman MA. Standard treatment in advanced ovarian cancer in 2005: the state of the art. Int J Gynecol Cancer. 2005; 15:212-20.

4. Kim A, Ueda Y, Naka T, Enomoto T. Therapeutic strategies in epithelial ovarian cancer. J Exp Clin Cancer Res. 2012; 31:14.
5. Rubin SC, Randall TC, Armstrong KA, Chi DS, Hoskins WJ. Ten-year follow-up of ovarian cancer patients after second-look laparotomy with negative findings. Obstet Gynecol. 1999; 93:21-4.

6. June $\mathrm{CH}$. Adoptive $\mathrm{T}$ cell therapy for cancer in the clinic. J Clin Invest. 2007; 117:1466-76.

7. Fujita K, Ikarashi H, Takakuwa K, Kodama S, Tokunaga A, Takahashi T, Tanaka K. Prolonged disease-free period in patients with advanced epithelial ovarian cancer after adoptive transfer of tumor-infiltrating lymphocytes. Clin Cancer Res. 1995; 1:501-7.

8. Aoki Y, Takakuwa K, Kodama S, Tanaka K, Takahashi M, Tokunaga A, Takahashi T. Use of adoptive transfer of tumor-infiltrating lymphocytes alone or in combination with cisplatin-containing chemotherapy in patients with epithelial ovarian cancer. Cancer Res. 1991; 51:1934-9.

9. Kalos M, Levine BL, Porter DL, Katz S, Grupp SA, Bagg A, June CH. T cells with chimeric antigen receptors have potent antitumor effects and can establish memory in patients with advanced leukemia. Sci Transl Med. 2011; 3:95ra73.

10. Koneru M, O'Cearbhaill R, Pendharkar S, Spriggs DR, Brentjens RJ. A phase I clinical trial of adoptive $\mathrm{T}$ cell therapy using IL-12 secreting MUC-16(ecto) directed chimeric antigen receptors for recurrent ovarian cancer. J Transl Med. 2015; 13:102.

11. Song DG, Ye Q, Carpenito C, Poussin M, Wang LP, Ji C, Figini $\mathrm{M}$, June $\mathrm{CH}$, Coukos $\mathrm{G}$, Powell DJ Jr. In vivo persistence, tumor localization, and antitumor activity of CAR-engineered T cells is enhanced by costimulatory signaling through CD137 (4-1BB). Cancer Res. 2011; 71:4617-27.

12. Hombach A, Hombach AA, Abken H. Adoptive immunotherapy with genetically engineered $\mathrm{T}$ cells: modification of the IgG1 Fc 'spacer' domain in the extracellular moiety of chimeric antigen receptors avoids 'off-target' activation and unintended initiation of an innate immune response. Gene Ther. 2010; 17:1206-13.

13. Hudecek M, Sommermeyer D, Kosasih PL, SilvaBenedict A, Liu L, Rader C, Jensen MC, Riddell SR. The nonsignaling extracellular spacer domain of chimeric antigen receptors is decisive for in vivo antitumor activity. Cancer Immunol Res. 2015; 3:125-35.

14. Harris DT, Kranz DM. Adoptive T Cell Therapies: A Comparison of $\mathrm{T}$ Cell Receptors and Chimeric Antigen Receptors. Trends Pharmacol Sci. 2016; 37:220-30.

15. Sadelain M, Brentjens R, Riviere I. The basic principles of chimeric antigen receptor design. Cancer Discov. 2013; 3:388-98.

16. Zhang Q, Zhang Z, Peng M, Fu S, Xue Z, Zhang R. CAR-T cell therapy in gastrointestinal tumors and hepatic carcinoma: From bench to bedside. Oncoimmunology. 2016; 5:e1251539.

17. Janda A, Eryilmaz E, Nakouzi A, Cowburn D, Casadevall A. Variable region identical immunoglobulins differing in 
isotype express different paratopes. J Biol Chem. 2012; 287:35409-17.

18. Wu Y, Jiang S, Ying T. From therapeutic antibodies to chimeric antigen receptors (CARs): making better CARs based on antigen-binding domain. Expert Opin Biol Ther. 2016; 16:1469-78.

19. Brocker T, Karjalainen K. Signals through T cell receptorzeta chain alone are insufficient to prime resting $\mathrm{T}$ lymphocytes. J Exp Med. 1995; 181:1653-9.

20. Brentjens RJ, Santos E, Nikhamin Y, Yeh R, Matsushita M, La Perle K, Quintas-Cardama A, Larson SM, Sadelain M. Genetically targeted $\mathrm{T}$ cells eradicate systemic acute lymphoblastic leukemia xenografts. Clin Cancer Res. 2007; 13:5426-35.

21. Imai $\mathrm{C}$, Mihara $\mathrm{K}$, Andreansky M, Nicholson $\mathrm{IC}$, Pui CH, Geiger TL, Campana D. Chimeric receptors with 4-1BB signaling capacity provoke potent cytotoxicity against acute lymphoblastic leukemia. Leukemia. 2004; 18:676-84.

22. Maher J, Brentjens RJ, Gunset G, Riviere I, Sadelain M. Human T-lymphocyte cytotoxicity and proliferation directed by a single chimeric TCRzeta /CD28 receptor. Nat Biotechnol. 2002; 20:70-5.

23. Song DG, Ye Q, Poussin M, Harms GM, Figini $M$, Powell DJ Jr. CD27 costimulation augments the survival and antitumor activity of redirected human T cells in vivo. Blood. 2012; 119:696-706.

24. Han EQ, Li XL, Wang CR, Li TF, Han SY. Chimeric antigen receptor-engineered $\mathrm{T}$ cells for cancer immunotherapy: progress and challenges. J Hematol Oncol. 2013; 6:47.

25. Wang J, Jensen M, Lin Y, Sui X, Chen E, Lindgren CG, Till B, Raubitschek A, Forman SJ, Qian X, James S, Greenberg P, Riddell S, et al. Optimizing adoptive polyclonal $\mathrm{T}$ cell immunotherapy of lymphomas, using a chimeric $\mathrm{T}$ cell receptor possessing CD28 and CD137 costimulatory domains. Hum Gene Ther. 2007; 18:712-25.

26. Ren J, Zhang X, Liu X, Fang C, Jiang S, June CH, Zhao Y. A versatile system for rapid multiplex genome-edited CAR T cell generation. Oncotarget. 2017; 8:17002-17011. http:// doi.org/10.18632/oncotarget.15218.

27. Chen C, Li K, Jiang H, Song F, Gao H, Pan X, Shi B, Bi Y, Wang H, Wang H, Li Z. Development of T cells carrying two complementary chimeric antigen receptors against glypican-3 and asialoglycoprotein receptor 1 for the treatment of hepatocellular carcinoma. Cancer Immunol Immunother. 2017; 66:475-89.

28. Hu WS, Pathak VK. Design of retroviral vectors and helper cells for gene therapy. Pharmacol Rev. 2000; 52:493-511.

29. Shimotohno K, Temin HM. Formation of infectious progeny virus after insertion of herpes simplex thymidine kinase gene into DNA of an avian retrovirus. Cell. 1981; 26:67-77.

30. Link CJ Jr, Moorman D, Seregina T, Levy JP, Schabold KJ. A phase I trial of in vivo gene therapy with the herpes simplex thymidine kinase/ganciclovir system for the treatment of refractory or recurrent ovarian cancer. Hum Gene Ther. 1996; 7:1161-79.
31. Tanaka K, Isselbacher KJ, Khoury G, Jay G. Reversal of oncogenesis by the expression of a major histocompatibility complex class I gene. Science. 1985; 228:26-30.

32. Barquinero J, Eixarch H, Perez-Melgosa M. Retroviral vectors: new applications for an old tool. Gene Ther. 2004; 11:S3-9.

33. Figueroa JA, Reidy A, Mirandola L, Trotter K, Suvorava N, Figueroa A, Konala V, Aulakh A, Littlefield L, Grizzi F, Rahman RL, Jenkins MR, Musgrove B, et al. Chimeric antigen receptor engineering: a right step in the evolution of adoptive cellular immunotherapy. Int Rev Immunol. 2015; 34:154-87.

34. Parker LL, Do MT, Westwood JA, Wunderlich JR, Dudley ME, Rosenberg SA, Hwu P. Expansion and characterization of T cells transduced with a chimeric receptor against ovarian cancer. Hum Gene Ther. 2000; 11:2377-87.

35. Westwood JA, Smyth MJ, Teng MW, Moeller M, Trapani JA, Scott AM, Smyth FE, Cartwright GA, Power BE, Honemann D, Prince HM, Darcy PK, Kershaw MH. Adoptive transfer of $\mathrm{T}$ cells modified with a humanized chimeric receptor gene inhibits growth of Lewis-Y-expressing tumors in mice. Proc Natl Acad Sci USA. 2005; 102:19051-6.

36. Lewinski MK, Bushman FD. Retroviral DNA integrationmechanism and consequences. Adv Genet. 2005; 55:147-81.

37. Miller DG, Adam MA, Miller AD. Gene transfer by retrovirus vectors occurs only in cells that are actively replicating at the time of infection. Mol Cell Biol. 1990; 10:4239-42.

38. De Meyer SF, Vanhoorelbeke K, Chuah MK, Pareyn I, Gillijns V, Hebbel RP, Collen D, Deckmyn H, VandenDriessche T. Phenotypic correction of von Willebrand disease type 3 blood-derived endothelial cells with lentiviral vectors expressing von Willebrand factor. Blood. 2006; 107:4728-36.

39. Indraccolo S, Habeler W, Tisato V, Stievano L, Piovan E, Tosello V, Esposito G, Wagner R, Uberla K, ChiecoBianchi L, Amadori A. Gene transfer in ovarian cancer cells: a comparison between retroviral and lentiviral vectors. Cancer Res. 2002; 62:6099-107.

40. Lewinski MK, Yamashita M, Emerman M, Ciuffi A, Marshall H, Crawford G, Collins F, Shinn P, Leipzig J, Hannenhalli S, Berry CC, Ecker JR, Bushman FD. Retroviral DNA integration: viral and cellular determinants of target-site selection. PLoS Pathog. 2006; 2:e60.

41. Song DG, Ye Q, Santoro S, Fang C, Best A, Powell DJ Jr. Chimeric NKG2D CAR-expressing T cell-mediated attack of human ovarian cancer is enhanced by histone deacetylase inhibition. Hum Gene Ther. 2013; 24:295-305.

42. Lanitis E, Poussin M, Hagemann IS, Coukos G, Sandaltzopoulos R, Scholler N, Powell DJ Jr. Redirected antitumor activity of primary human lymphocytes transduced with a fully human anti-mesothelin chimeric receptor. Mol Ther. 2012; 20:633-43.

43. Li Q, Kay MA, Finegold M, Stratford-Perricaudet LD, Woo SL. Assessment of recombinant adenoviral vectors for hepatic gene therapy. Hum Gene Ther. 1993; 4:403-9. 
44. Doerfler W, Schubbert R, Heller H, Hertz J, Remus R, Schroer J, Kammer C, Hilger-Eversheim K, Gerhardt U, Schmitz B, Renz D, Schell G. Foreign DNA in mammalian systems. APMIS Suppl. 1998; 84:62-8.

45. Engelhardt JF, Ye X, Doranz B, Wilson JM. Ablation of $\mathrm{E} 2 \mathrm{~A}$ in recombinant adenoviruses improves transgene persistence and decreases inflammatory response in mouse liver. Proc Natl Acad Sci USA. 1994; 91:6196-200.

46. Roy I, Holle L, Song W, Holle E, Wagner T, Yu X. Efficient translocation and apoptosis induction by adenovirus encoded VP22-p53 fusion protein in human tumor cells in vitro. Anticancer Res. 2002; 22:3185-9.

47. Wu H, Wang K, Liu W, Hao Q. Recombinant adenovirusmediated overexpression of PTEN and KRT10 improves cisplatin resistance of ovarian cancer in vitro and in vivo. Genet Mol Res. 2015; 14:6591-7.

48. Rein DT, Volkmer A, Beyer IM, Curiel DT, Janni W, Dragoi A, Hess AP, Maass N, Baldus SE, Bauerschmitz G, Breidenbach M. Treatment of chemotherapy resistant ovarian cancer with a MDR1 targeted oncolytic adenovirus. Gynecol Oncol. 2011; 123:138-46.

49. Jaras M, Brun AC, Karlsson S, Fan X. Adenoviral vectors for transient gene expression in human primitive hematopoietic cells: applications and prospects. Exp Hematol. 2007; 35:343-9.

50. Wu H, Han T, Lam JT, Leath CA, Dmitriev I, Kashentseva E, Barnes MN, Alvarez RD, Curiel DT. Preclinical evaluation of a class of infectivity-enhanced adenoviral vectors in ovarian cancer gene therapy. Gene Ther. 2004; 11:874-8.

51. Choi VW, McCarty DM, Samulski RJ. AAV hybrid serotypes: improved vectors for gene delivery. Curr Gene Ther. 2005; 5:299-310.

52. Alexander IE, Russell DW, Spence AM, Miller AD. Effects of gamma irradiation on the transduction of dividing and nondividing cells in brain and muscle of rats by adenoassociated virus vectors. Hum Gene Ther. 1996; 7:841-50.

53. Bui Nguyen TM, Subramanian IV, Xiao X, Nguyen P, Ramakrishnan S. Adeno-associated virus-mediated delivery of kringle 5 of human plasminogen inhibits orthotopic growth of ovarian cancer. Gene Ther. 2010; 17:606-15.

54. Isayeva $\mathrm{T}$, Ren $\mathrm{C}$, Ponnazhagan S. Recombinant adenoassociated virus 2 -mediated antiangiogenic prevention in a mouse model of intraperitoneal ovarian cancer. Clin Cancer Res. 2005; 11:1342-7.

55. Kaminski JM, Huber MR, Summers JB, Ward MB. Design of a nonviral vector for site-selective, efficient integration into the human genome. FASEB J. 2002; 16:1242-7.

56. Fraley R, Subramani S, Berg P, Papahadjopoulos D. Introduction of liposome-encapsulated SV40 DNA into cells. J Biol Chem. 1980; 255:10431-5.

57. Yu D, Matin A, Xia W, Sorgi F, Huang L, Hung MC. Liposome-mediated in vivo E1A gene transfer suppressed dissemination of ovarian cancer cells that overexpress HER-2/neu. Oncogene. 1995; 11:1383-8.
58. Li W, Szoka FC Jr. Lipid-based nanoparticles for nucleic acid delivery. Pharm Res. 2007; 24:438-49.

59. Ruponen M, Yla-Herttuala S, Urtti A. Interactions of polymeric and liposomal gene delivery systems with extracellular glycosaminoglycans: physicochemical and transfection studies. Biochim Biophys Acta. 1999; 1415:331-41.

60. Kim CK, Haider KH, Choi SH, Choi EJ, Ahn WS, Kim YB. Nonviral vector for efficient gene transfer to human ovarian adenocarcinoma cells. Gynecol Oncol. 2002; 84:85-93.

61. Leventis R, Silvius JR. Interactions of mammalian cells with lipid dispersions containing novel metabolizable cationic amphiphiles. Biochim Biophys Acta. 1990; 1023:124-32.

62. Behr JP, Demeneix B, Loeffler JP, Perez-Mutul J. Efficient gene transfer into mammalian primary endocrine cells with lipopolyamine-coated DNA. Proc Natl Acad Sci USA. 1989; 86:6982-6.

63. Nabel GJ, Nabel EG, Yang ZY, Fox BA, Plautz GE, Gao X, Huang L, Shu S, Gordon D, Chang AE. Direct gene transfer with DNA-liposome complexes in melanoma: expression, biologic activity, and lack of toxicity in humans. Proc Natl Acad Sci USA. 1993; 90:11307-11.

64. Hacein-Bey-Abina S, Garrigue A, Wang GP, Soulier J, Lim A, Morillon E, Clappier E, Caccavelli L, Delabesse E, Beldjord K, Asnafi V, MacIntyre E, Dal Cortivo L, et al. Insertional oncogenesis in 4 patients after retrovirusmediated gene therapy of SCID-X1. J Clin Invest. 2008; 118:3132-42.

65. Lamers CH, Sleijfer S, van Steenbergen S, van Elzakker $P$, van Krimpen B, Groot C, Vulto A, den Bakker M, Oosterwijk E, Debets R, Gratama JW. Treatment of metastatic renal cell carcinoma with CAIX CAR-engineered $\mathrm{T}$ cells: clinical evaluation and management of on-target toxicity. Mol Ther. 2013; 21:904-12.

66. Zhao Y, Moon E, Carpenito C, Paulos CM, Liu X, Brennan AL, Chew A, Carroll RG, Scholler J, Levine BL, Albelda SM, June CH. Multiple injections of electroporated autologous $\mathrm{T}$ cells expressing a chimeric antigen receptor mediate regression of human disseminated tumor. Cancer Res. 2010; 70:9053-61.

67. Zhao Y, Zheng Z, Cohen CJ, Gattinoni L, Palmer DC, Restifo NP, Rosenberg SA, Morgan RA. High-efficiency transfection of primary human and mouse $\mathrm{T}$ lymphocytes using RNA electroporation. Mol Ther. 2006; 13:151-9.

68. Kenderian SS, Ruella M, Shestova O, Klichinsky M, Aikawa V, Morrissette JJ, Scholler J, Song D, Porter DL, Carroll M, June CH, Gill S. CD33-specific chimeric antigen receptor $\mathrm{T}$ cells exhibit potent preclinical activity against human acute myeloid leukemia. Leukemia. 2015; 29:1637-47.

69. Hackett PB, Largaespada DA, Switzer KC, Cooper LJ. Evaluating risks of insertional mutagenesis by DNA transposons in gene therapy. Transl Res. 2013; 161:265-83.

70. Qin DY, Huang Y, Li D, Wang YS, Wang W, Wei YQ. Paralleled comparison of vectors for the generation of CAR-T cells. Anticancer Drugs. 2016; 27:711-22. 
71. Hackett CS, Geurts AM, Hackett PB. Predicting preferential DNA vector insertion sites: implications for functional genomics and gene therapy. Genome Biol. 2007; 8:S12

72. Singh H, Huls H, Kebriaei P, Cooper LJ. A new approach to gene therapy using Sleeping Beauty to genetically modify clinical-grade T cells to target CD19. Immunol Rev. 2014; 257:181-90.

73. Mates L, Chuah MK, Belay E, Jerchow B, Manoj N, Acosta-Sanchez A, Grzela DP, Schmitt A, Becker K, Matrai J, Ma L, Samara-Kuko E, Gysemans C, et al. Molecular evolution of a novel hyperactive Sleeping Beauty transposase enables robust stable gene transfer in vertebrates. Nat Genet. 2009; 41:753-61.

74. Delhove J, Qasim W. Genome-Edited T Cell Therapies. Curr Stem Cell Rep. 2017; 3:124-36.

75. Brentjens RJ, Riviere I, Park JH, Davila ML, Wang X, Stefanski J, Taylor C, Yeh R, Bartido S, Borquez-Ojeda O, Olszewska M, Bernal Y, Pegram H, et al. Safety and persistence of adoptively transferred autologous CD19targeted $\mathrm{T}$ cells in patients with relapsed or chemotherapy refractory B-cell leukemias. Blood. 2011; 118:4817-28.

76. Porter DL, Levine BL, Kalos M, Bagg A, June CH. Chimeric antigen receptor-modified $\mathrm{T}$ cells in chronic lymphoid leukemia. N Engl J Med. 2011; 365:725-33.

77. Zhang BL, Qin DY, Mo ZM, Li Y, Wei W, Wang YS, Wang W, Wei YQ. Hurdles of CAR-T cell-based cancer immunotherapy directed against solid tumors. Sci China Life Sci. 2016; 59:340-8.

78. Zhang H, Ye ZL, Yuan ZG, Luo ZQ, Jin HJ, Qian QJ. New Strategies for the Treatment of Solid Tumors with CAR-T Cells. Int J Biol Sci. 2016; 12:718-29.

79. Slaney CY, Kershaw MH, Darcy PK. Trafficking of T cells into tumors. Cancer Res. 2014; 74:7168-74.

80. Park HJ, Kusnadi A, Lee EJ, Kim WW, Cho BC, Lee IJ, Seong J, Ha SJ. Tumor-infiltrating regulatory $\mathrm{T}$ cells delineated by upregulation of PD-1 and inhibitory receptors. Cell Immunol. 2012; 278:76-83.

81. Sadelain M, Riviere I, Brentjens R. Targeting tumours with genetically enhanced T lymphocytes. Nat Rev Cancer. $2003 ; 3: 35-45$.

82. Kandalaft LE, Powell DJ Jr, Coukos G. A phase I clinical trial of adoptive transfer of folate receptor-alpha redirected autologous $\mathrm{T}$ cells for recurrent ovarian cancer. J Transl Med. 2012; 10:157.

83. Lavoue V, Thedrez A, Leveque J, Foucher F, Henno S, Jauffret V, Belaud-Rotureau MA, Catros V, Cabillic F. Immunity of human epithelial ovarian carcinoma: the paradigm of immune suppression in cancer. J Transl Med. 2013; 11:147.

84. Zhang L, Conejo-Garcia JR, Katsaros D, Gimotty PA, Massobrio M, Regnani G, Makrigiannakis A, Gray H, Schlienger K, Liebman MN, Rubin SC, Coukos G. Intratumoral $\mathrm{T}$ cells, recurrence, and survival in epithelial ovarian cancer. N Engl J Med. 2003; 348:203-13.
85. Hwang WT, Adams SF, Tahirovic E, Hagemann IS, Coukos G. Prognostic significance of tumor-infiltrating T cells in ovarian cancer: a meta-analysis. Gynecol Oncol. 2012; 124:192-8.

86. Knutson KL, Maurer MJ, Preston CC, Moysich KB, Goergen K, Hawthorne KM, Cunningham JM, Odunsi K, Hartmann LC, Kalli KR, Oberg AL, Goode EL. Regulatory T cells, inherited variation, and clinical outcome in epithelial ovarian cancer. Cancer Immunol Immunother. 2015; 64:1495-504.

87. Berezhnaya NM. Interaction between tumor and immune system: the role of tumor cell biology. Exp Oncol. 2010; 32:159-66.

88. Han LY, Fletcher MS, Urbauer DL, Mueller P, Landen CN, Kamat AA, Lin YG, Merritt WM, Spannuth WA, Deavers MT, De Geest K, Gershenson DM, Lutgendorf SK, et al. HLA class I antigen processing machinery component expression and intratumoral T-Cell infiltrate as independent prognostic markers in ovarian carcinoma. Clin Cancer Res. 2008; 14:3372-9.

89. Dunn GP, Bruce AT, Ikeda H, Old LJ, Schreiber RD. Cancer immunoediting: from immunosurveillance to tumor escape. Nat Immunol. 2002; 3:991-8.

90. Cheadle EJ, Gornall H, Baldan V, Hanson V, Hawkins RE, Gilham DE. CAR T cells: driving the road from the laboratory to the clinic. Immunol Rev. 2014; 257:91-106.

91. Andersson E, Villabona L, Bergfeldt K, Carlson JW, Ferrone S, Kiessling R, Seliger B, Masucci GV. Correlation of HLA-A02* genotype and HLA class I antigen downregulation with the prognosis of epithelial ovarian cancer. Cancer Immunol Immunother. 2012; 61:1243-53.

92. Maus MV, Grupp SA, Porter DL, June CH. Antibodymodified T cells: CARs take the front seat for hematologic malignancies. Blood. 2014; 123:2625-35.

93. Jena B, Dotti G, Cooper LJ. Redirecting T-cell specificity by introducing a tumor-specific chimeric antigen receptor. Blood. 2010; 116:1035-44.

94. Sadelain M, Brentjens R, Riviere I. The promise and potential pitfalls of chimeric antigen receptors. Curr Opin Immunol. 2009; 21:215-23.

95. Singh AP, Senapati S, Ponnusamy MP, Jain M, Lele SM, Davis JS, Remmenga S, Batra SK. Clinical potential of mucins in diagnosis, prognosis, and therapy of ovarian cancer. Lancet Oncol. 2008; 9:1076-85.

96. Fritsche HA, Bast RC. CA 125 in ovarian cancer: advances and controversy. Clin Chem. 1998; 44:1379-80.

97. O'Brien TJ, Beard JB, Underwood LJ, Dennis RA, Santin AD, York L. The CA 125 gene: an extracellular superstructure dominated by repeat sequences. Tumour Biol. 2001; 22:348-66.

98. Bouanene H, Miled A. Conflicting views on the molecular structure of the cancer antigen CA125/MUC16. Dis Markers. 2010; 28:385-94.

99. Wang Y, Cheon DJ, Lu Z, Cunningham SL, Chen CM, Luo RZ, Xing D, Orsulic S, Bast RC Jr, Behringer RR. 
MUC16 expression during embryogenesis, in adult tissues, and ovarian cancer in the mouse. Differentiation. 2008; 76:1081-92.

100. Chekmasova AA, Rao TD, Nikhamin Y, Park KJ, Levine DA, Spriggs DR, Brentjens RJ. Successful eradication of established peritoneal ovarian tumors in SCID-Beige mice following adoptive transfer of $\mathrm{T}$ cells genetically targeted to the MUC16 antigen. Clin Cancer Res. 2010; 16:3594-606.

101. Campbell IG, Jones TA, Foulkes WD, Trowsdale J. Folatebinding protein is a marker for ovarian cancer. Cancer Res. 1991; 51:5329-38.

102. Leamon CP, Low PS. Delivery of macromolecules into living cells: a method that exploits folate receptor endocytosis. Proc Natl Acad Sci USA. 1991; 88:5572-6.

103. Toffoli G, Cernigoi C, Russo A, Gallo A, Bagnoli M, Boiocchi M. Overexpression of folate binding protein in ovarian cancers. Int J Cancer. 1997; 74:193-8.

104. Hartmann LC, Keeney GL, Lingle WL, Christianson TJ, Varghese B, Hillman D, Oberg AL, Low PS. Folate receptor overexpression is associated with poor outcome in breast cancer. Int J Cancer. 2007; 121:938-42.

105. Coney LR, Tomassetti A, Carayannopoulos L, Frasca V, Kamen BA, Colnaghi MI, Zurawski VR Jr. Cloning of a tumor-associated antigen: MOv18 and MOv19 antibodies recognize a folate-binding protein. Cancer Res. 1991; 51:6125-32.

106. Canevari S, Stoter G, Arienti F, Bolis G, Colnaghi MI, Di Re EM, Eggermont AM, Goey SH, Gratama JW, Lamers $\mathrm{CH}$, et al. Regression of advanced ovarian carcinoma by intraperitoneal treatment with autologous $\mathrm{T}$ lymphocytes retargeted by a bispecific monoclonal antibody. J Natl Cancer Inst. 1995; 87:1463-9.

107. Kershaw MH, Westwood JA, Parker LL, Wang G, Eshhar Z, Mavroukakis SA, White DE, Wunderlich JR, Canevari S, Rogers-Freezer L, Chen CC, Yang JC, Rosenberg SA, et al. A phase I study on adoptive immunotherapy using gene-modified T cells for ovarian cancer. Clin Cancer Res. 2006; 12:6106-15.

108. Chang K, Pastan I. Molecular cloning of mesothelin, a differentiation antigen present on mesothelium, mesotheliomas, and ovarian cancers. Proc Natl Acad Sci USA. 1996; 93:136-40.

109. Argani P, Iacobuzio-Donahue C, Ryu B, Rosty C, Goggins M, Wilentz RE, Murugesan SR, Leach SD, Jaffee E, Yeo CJ, Cameron JL, Kern SE, Hruban RH. Mesothelin is overexpressed in the vast majority of ductal adenocarcinomas of the pancreas: identification of a new pancreatic cancer marker by serial analysis of gene expression (SAGE). Clin Cancer Res. 2001; 7:3862-8.

110. Ho M, Bera TK, Willingham MC, Onda M, Hassan R, FitzGerald D, Pastan I. Mesothelin expression in human lung cancer. Clin Cancer Res. 2007; 13:1571-5.

111. Maeda M, Hino O. Molecular tumor markers for asbestosrelated mesothelioma: serum diagnostic markers. Pathol Int. 2006; 56:649-54.
112. Hassan R, Kreitman RJ, Pastan I, Willingham MC. Localization of mesothelin in epithelial ovarian cancer. Appl Immunohistochem Mol Morphol. 2005; 13:243-7.

113. Kaneko O, Gong L, Zhang J, Hansen JK, Hassan R, Lee B, Ho M. A binding domain on mesothelin for CA125/ MUC16. J Biol Chem. 2009; 284:3739-49.

114. Cheng WF, Huang CY, Chang MC, Hu YH, Chiang YC, Chen YL, Hsieh CY, Chen CA. High mesothelin correlates with chemoresistance and poor survival in epithelial ovarian carcinoma. Br J Cancer. 2009; 100:1144-53.

115. Carpenito C, Milone MC, Hassan R, Simonet JC, Lakhal M, Suhoski MM, Varela-Rohena A, Haines KM, Heitjan DF, Albelda SM, Carroll RG, Riley JL, Pastan I, et al. Control of large, established tumor xenografts with genetically retargeted human T cells containing CD28 and CD137 domains. Proc Natl Acad Sci USA. 2009; 106:3360-5.

116. Bargmann CI, Hung MC, Weinberg RA. The neu oncogene encodes an epidermal growth factor receptor-related protein. Nature. 1986; 319:226-30.

117. Wong YF, Cheung TH, Lam SK, Lu HJ, Zhuang YL, Chan MY, Chung TK. Prevalence and significance of HER2/neu amplification in epithelial ovarian cancer. Gynecol Obstet Invest. 1995; 40:209-12.

118. Wilken JA, Badri T, Cross S, Raji R, Santin AD, Schwartz P, Branscum AJ, Baron AT, Sakhitab AI, Maihle NJ. EGFR/ HER-targeted therapeutics in ovarian cancer. Future Med Chem. 2012; 4:447-69.

119. Slamon DJ, Clark GM, Wong SG, Levin WJ, Ullrich A, McGuire WL. Human breast cancer: correlation of relapse and survival with amplification of the HER-2/neu oncogene. Science. 1987; 235:177-82.

120. Hirsch FR, Varella-Garcia M, Franklin WA, Veve R, Chen L, Helfrich B, Zeng C, Baron A, Bunn PA Jr. Evaluation of HER-2/neu gene amplification and protein expression in non-small cell lung carcinomas. Br J Cancer. 2002; 86:1449-56.

121. Lafky JM, Wilken JA, Baron AT, Maihle NJ. Clinical implications of the ErbB/epidermal growth factor (EGF) receptor family and its ligands in ovarian cancer. Biochim Biophys Acta. 2008; 1785:232-65.

122. Orlandi A, Fasciani R, Cassano A, Agresta A, Calegari MA, Caporossi A, Barone C. Trastuzumab-induced corneal ulceration: successful no-drug treatment of a "blind" side effect in a case report. BMC Cancer. 2015; 15:973.

123. Ghani EA, Kerr I, Dada R. Grade 3 trastuzumab-induced neutropenia in breast cancer patient. J Oncol Pharm Pract. 2014; 20:154-7.

124. Sendur MA, Aksoy S, Yorgun H, Ozdemir N, Yilmaz FM, Yazici O, Zungun C, Aytemir K, Zengin N, Altundag K. Comparison of the long term cardiac effects associated with 9 and 52 weeks of trastuzumab in HER2-positive early breast cancer. Curr Med Res Opin. 2015; 31:547-56.

125. Sun M, Shi H, Liu C, Liu J, Liu X, Sun Y. Construction and evaluation of a novel humanized HER2-specific chimeric receptor. Breast Cancer Res. 2014; 16:R61. 
126. Hegde M, Mukherjee M, Grada Z, Pignata A, Landi D, Navai SA, Wakefield A, Fousek K, Bielamowicz K, Chow KK, Brawley VS, Byrd TT, Krebs S, et al. Tandem CAR T cells targeting HER2 and IL13Ralpha2 mitigate tumor antigen escape. J Clin Invest. 2016; 126:3036-52.

127. Magee MS, Snook AE. Challenges to chimeric antigen receptor (CAR)-T cell therapy for cancer. Discov Med. 2014; 18:265-71.

128. Tanyi JL, Stashwick C, Plesa G, Morgan MA, Porter D, Maus MV, June CH. Possible Compartmental Cytokine Release Syndrome in a Patient With Recurrent Ovarian Cancer After Treatment With Mesothelin-targeted CAR-T Cells. J Immunother. 2017; 40:104-7.

129. Lee DW, Gardner R, Porter DL, Louis CU, Ahmed N, Jensen M, Grupp SA, Mackall CL. Current concepts in the diagnosis and management of cytokine release syndrome. Blood. 2014; 124:188-95.

130. Johnson LA, Morgan RA, Dudley ME, Cassard L, Yang JC, Hughes MS, Kammula US, Royal RE, Sherry RM, Wunderlich JR, Lee CC, Restifo NP, Schwarz SL, et al. Gene therapy with human and mouse T-cell receptors mediates cancer regression and targets normal tissues expressing cognate antigen. Blood. 2009; 114:535-46.

131. Morgan RA, Yang JC, Kitano M, Dudley ME, Laurencot CM, Rosenberg SA. Case report of a serious adverse event following the administration of $\mathrm{T}$ cells transduced with a chimeric antigen receptor recognizing ERBB2. Mol Ther. 2010; 18:843-51.
132. Akpek G, Lee SM, Anders V, Vogelsang GB. A high-dose pulse steroid regimen for controlling active chronic graftversus-host disease. Biol Blood Marrow Transplant. 2001; 7:495-502.

133. Davila ML, Sauter C, Brentjens R. CD19-Targeted T Cells for Hematologic Malignancies: Clinical Experience to Date. Cancer J. 2015; 21:470-4.

134. Bonini C, Ferrari G, Verzeletti S, Servida P, Zappone E, Ruggieri L, Ponzoni M, Rossini S, Mavilio F, Traversari C, Bordignon C. HSV-TK gene transfer into donor lymphocytes for control of allogeneic graft-versusleukemia. Science. 1997; 276:1719-24.

135. Straathof KC, Pule MA, Yotnda P, Dotti G, Vanin EF, Brenner MK, Heslop HE, Spencer DM, Rooney CM. An inducible caspase 9 safety switch for T-cell therapy. Blood. 2005; 105:4247-54.

136. Kim KH, Dmitriev I, O’Malley JP, Wang M, Saddekni S, You Z, Preuss MA, Harris RD, Aurigemma R, Siegal GP, Zinn KR, Curiel DT, Alvarez RD. A phase I clinical trial of Ad5.SSTR/TK.RGD, a novel infectivity-enhanced bicistronic adenovirus, in patients with recurrent gynecologic cancer. Clin Cancer Res. 2012; 18:3440-51.

137. Seton-Rogers S. Immunotherapy: Two antigens are better than one. Nat Rev Cancer. 2016; 16:128-9.

138. Juillerat A, Marechal A, Filhol JM, Valogne Y, Valton J, Duclert A, Duchateau P, Poirot L. An oxygen sensitive selfdecision making engineered CAR T-cell. Sci Rep. 2017; $7: 39833$. 